\section{Hledání původu}

\section{koncepce}

\section{rovnovážného}

\section{umístění Země}

SEARCHING FOR ORIGINS OF EARTH

STABILITY CONCEPTION

\section{RADIM KOČANDRLE}

Fakulta filozofická

Západočeská univerzita v Plzni

Sedláčkova 38

30614 Plzeň

rkocandr@kfi.zcu.cz

\section{ABSTRAKT}

In his De caelo, Aristotle ascribes to Anaximander of Miletus a conception according to which the Earth remains at its place in the universe only thanks to the symmetry of its position. Simplicius, however, in his commentary on this passage from Aristotle, notes that such a formulation can also be found in Plato. Aetius, meanwhile, ascribes this entire argument to Parmenides and Democritus. Plato shows that the validity of this argument is based on the assumption that both the Earth and the universe that surrounds it are spherical. Anaximander, however, in all likelihood, believes the Earth to be flat - a feature typical of Ionian cosmology. Given that a belief in a spherical shape of the universe and the Earth can be demonstrated in the Pythagorean School and is hinted upon in Parmenides, we could assume that this conception originated in the Italian branch of philosophy. And since we do not have enough texts to satisfactorily reconstruct Pythagorean thoughts and have to rely on much later reports by Philolaus, one could assume that the whole argument about the stability of the Earth due to equilibrium and symmetry is based on Parmenides's thoughts." 
Aristotelés ve spisu $O$ nebi představuje názory svých předchůdců, které se mimo jiné týkají zdůvodnění stability Země v univerzu. Anaximandrovi z Mílétu připisuje pojetí, podle něhož Země zůstávala nehybně na místě pouze díky svému souměrnému umístění. V komentáři k této Aristotelově pasáži ovšem Simplikios upozorňuje, že danou formulaci můžeme nalézt u Platóna. Áetios celý argument navíc přisuzuje Parmenidovi a Démokritovi.

Ačkoli badatelé obvykle uvedenou koncepci přijímají za autentickou, již dříve jsme upozornili, že neodpovídá povaze Anaximandrova univerza. ${ }^{1}$ Pokud jsme však poukázali na to, že daný argument od Mílétana nepochází, měli

1 Zejména srov. Kočandrle 2016. Podobně viz Kočandrle 2010, s. 271-281; 2012; 2013. bychom zároveň nalézt jeho skutečného autora. V této studii si proto položíme otázku po původu celého pojetí. Navážeme přitom na naše předchozí interpretace a postupně opět nahlédneme do textů, které se k problému vyslovují. Následně poukážeme na zásadní rozdíly v kosmologii iónské a italské větve filosofie, jež rozlišuje Diogenés Laertios. Upozorníme na to, že zmíněná koncepce vychází až z charakteru italské větve, přičemž uvedeme jejího pravděpodobného autora.

\section{ARGUMENT O STABILITĚ ZEMĚ}

Pokud shrneme textovou evidenci, musíme především znovu přiblížit znění celého argumentu, jak jej podává Aristotelés ve spisu $O$ nebi. Ve 13. kapitole II. knihy představuje názory svých 
předchůdců jak na umístění Země v univerzu, tak na její tvar a případný klid, či naopak pohyb. U koncepcí předpokládajících nehybnou Zemi si přitom všímá odůvodnění jejího setrvávání na místě. Oproti naprosté většině myslitelů, kteří předpokládali konkrétní vnější oporu Země, jako byla voda nebo vzduch či působení víru, přihlédne nakonec i ke zdůvodnění, které vycházelo ze zcela jiných předpokladů. Stabilita Země se měla zakládat pouze na platnosti následujícího argumentu: ${ }^{2}$

„Jsou však tací, kteří tvrdí, že Země setrvává v klidu ( $\mu$ ćveıv) díky souměrnosti

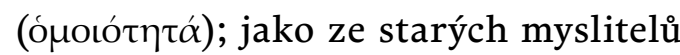
Anaximandros. Nic, co je usazeno ve středu a je stejně (ómoíws) vzdálené od krajů, se nemůže pohybovat spíše nahoru, dolů nebo do stran. Současně je nemožné, aby se to pohybovalo v protikladných směrech, takže nutně setrvává v klidu." ${ }^{3}$

V případě předcházejících koncepcí to měl být obvykle plochý tvar či váha Země, co vstupovalo do interakce s působením vnějšího prvku a stabilitu Země spoluurčovalo. Nyní je však zřejmé, že nehybnost Země zajištují pouze samotné proporční poměry $\mathrm{v}$ univerzu. Je přitom pozoruhodné, že Aristotelés se $\mathrm{k}$ nim vůbec nevyjadřuje, nebot' nezmiňuje ani tvar Země či obklopujícího okolí. Nejprve pouze lakonicky uvádí

2 Srov. Bodnár 1992, s. 336.

3 Aristotelés, De caelo $1 \mathrm{I}, 13,295 \mathrm{~b} 10=D K 12$ A 26. Není-li uvedeno jinak, překlady antických autorů pořídili na základě staršich překladů V. Hladký a kol.

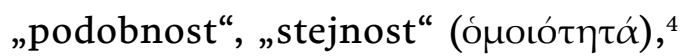
úzce související se souměrností a rovnováhou, díky níž měla Země nehybně setrvávat na svém místě. Vzápětí nicméně uvádí dvě konkrétní podmínky klidu Země - umístění ve středu a ve shodné vzdálenosti od krajů. Ve svém důsledku to mělo být právě souměrné umístění Země vưči celému jejímu okolí, co vedlo k její rovnováze a nehybnosti. ${ }^{5}$

Na první pohled se může zdát, že k Anaximandrovi se vztahuje pouze explicitní zmínka o souměrnosti, zatímco následující argument je až vlastním Aristotelovým rozvedením. Z dalšího textu je však zřejmé, že právě dané rozvedení je tím, na co Aristotelés reaguje, přičemž termín ó stavovat pouze opis, který generálně vystihuje celé pojetí. Lze se přitom domnívat, že daný termín v uvedeném technickém smyslu od Anaximandra nepochází. Bezprostředně nato se ale objevuje termín ónoíws. U Homéra lze termín ó oĩo $^{6}$ opakovaně doložit ve významu shodného či podobného vztahu mezi lidmi či věcmi. Není proto vyloučeno, že Aristotelés přece jen i terminologicky reaguje na některou původní zprávu. Dále uvidíme, že již Platón užívá ve stejném kontextu v dialogu Faidón

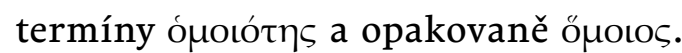
Podobně se setkáme s termíny ónóv a ó $\mu \tilde{\omega} \varsigma$ u Parmenida. ${ }^{7}$

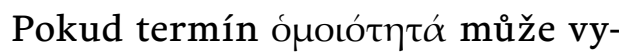
jadřovat pouze obecné vystižení stavu,

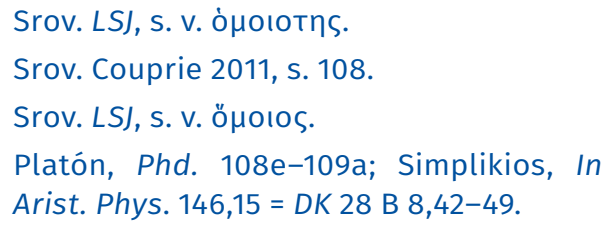


zdá se, že klíčový je až vlastní popis celé situace, nebot's ním Aristotelés v dalším textu polemizuje. Zatímco u předchozích koncepcí přicházely ke slovu různé vlastnosti Země spolu s působením okolního prostředí, nyní Aristotelés explicitně uvádí pouze vliv podobnosti. Přesto do hry zásadně vstupuje jak umístění Země, tak okolní prostředí a jejich role nám

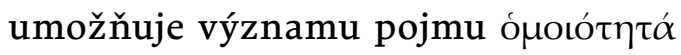
vůbec porozumět. ${ }^{8}$ Klid tělesa se má totiž přímo zakládat na dvou vztažných podmínkách: těleso musí být umístěno ve středu a zároveň se nalézat ve shodné vzdálenosti od krajů. Klidový stav Země v univerzu se tak odvíjí z jejího rovnovážného umístění, přičemž obě podmínky přímo vycházejí z charakteru vnějšího okolí. Oproti případnému působení vzduchu či jiného média směřuje celý argument k tvaru či uspořádání okolí, v němž se Země nalézá. Pokud je Země umístěna v samém středu univerza a zároveň ve shodné vzdálenosti od jeho krajů, můžeme hovořit o uplatnění souměrnosti. Tehdy se Země nalézá v rovnováze, nemá tendenci pohybovat se žádným směrem, a nutně tak setrvává $\mathrm{v}$ klidu na svém místě. Uvedený argument bývá pokládán za jednu z prvních formulací principu dostatečného důvodu, který je možné doložit například u Leukippa. ${ }^{9,10}$

Je evidentní, že dané pojetí Aristotela zaujalo, nebot' mu věnuje velkou

Srov. překladatelskou poznámku W. K. C. Guthrieho in: Aristotle 2006, s. 234, pozn. a.

9 Áetios, Plac. I,25,4 Diels-Kranz = DK 67 B 2.

10 Srov. Couprie 2011, s. 108-109; Hahn 2010, s. 55-56; McKirahan 1994, s. 40; Robinson 1971, s. 112. pozornost. Vypovídá o tom již samotný rozsah textu, který zabírá celý závěr 13. kapitoly, navíc předtím než ve 14 . kapitole Aristotelés představí vlastní pojetí Země. S výjimkou koncepce víru tak rozsah pasáže spíše kontrastuje s ostatními kritickými poznámkami k jiným myslitelům - zvláště přihlédneme-li k Anaximandrovým iónským současníkům. Aristotelés celý argument nejprve charakteristicky označuje za „důmyslný, ale nepravdivý“. ${ }^{11}$ Následně s ním polemizuje a vyvíjí poměrně velké úsilí, aby ukázal, že není platný. Podle něho je to až jeho vlastní teorie přirozených míst, která dostatečně vysvětluje rozličné problémy přítomné $\mathrm{v}$ koncepcích předchůdců.

Lze se domnívat, že Aristotelés věnuje celému argumentu nezvykle mnoho prostoru proto, že se v něm vypořádává s pojetím, které nejvíce směřuje jeho vlastním směrem - směrem ke konečnému sférickému univerzu sestávajícímu z koncentrických sfér, na nichž jsou nesena nebeská tělesa a jež se otáčejí kolem kulové Země ve středu. Podle Aristotela se však Země nalézá ve středu univerza na základě teorie přirozených míst, kdy ke středu jako taková přirozeně směřuje.

\section{SIMPLIKIOS A PLATÓN}

Ačkoli o Anaximandrově koncepci umístění Země v univerzu referují ještě další autoři, ponecháme jejich zprávy nyní stranou. Přihlédneme naopak k Simplikiovu komentáři k Aristotelově pasáži ze spisu $O$ nebi. Simplikios zde totiž přináší vlastní doplňující pohled na

11 Aristotelés, De caelo II,13,295b16. 
Anaximandrovo pojetí. Zejména však upozorňuje na to, že celou formulaci můžeme nalézt u Platóna. Táže se přitom po jejím skutečném původu. Pokud $\mathrm{v}$ dnešní době hledáme autora celé koncepce, máme tedy právě v osobě Simplikia doloženu situaci, kdy již antický myslitel postupuje stejným směrem.

Oproti Aristotelovu původnímu podání Simplikios zmiňuje hned tři konkrétní podmínky zajištující umístění Země v univerzu:

„Anaximandros se pak domníval, že Země zůstává nahoře (

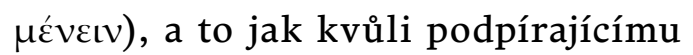
vzduchu, tak kvůli rovnováze a souměr-

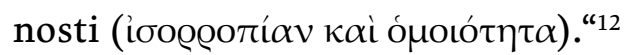

Země je podle něho „držena nahoře“ v prvé řadě působením vzduchu. Tato podmínka je v naprostém protikladu k Aristotelovu tvrzení, nebot'Anaximandrovi přisuzuje myšlenku konkrétního vnějšího fyzikálního působení, kterou měli zastávat ostatní myslitelé. Vevazuje jej tak zpět do iónské tradice. Zároveň tím „boříc Aristotelem pojednávaný argument, který právě od vnějšího působení odhlížel, a byl proto Aristotelem kriticky, nicméně s velkým zájmem traktován.

Simplikios následně přidává ještě dvě další podmínky, které jsou již s argumentem v souladu: rovnováhu a souměrnost. Může být přitom zajímavé, že souměrnost zmiňovanou Aristotelem uvádí jako poslední. Užívá přitom ter-

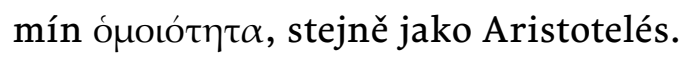

Rovnováha se naproti tomu u Aristotela explicitně neobjevuje, přestože $z$ jeho argumentu vyplývá. Ačkoli jsou všechny tři podmínky uvedeny zdánlivě v rovném postavení, $\mathrm{z}$ celého vyjádření se přesto může na první pohled zdát, že jejich role rovnocenná není. Jako by totiž právě aktivní působení vzduchu zakládalo samotnou možnost klidového stavu Země, zatímco přítomnost obou zbývajících podmínek byla až dodatečná. Jsou to však právě rovnováha a souměrnost, $\mathrm{k}$ nimž Simplikios v dalším textu přihlíží.

Uvedení vzduchu se tak může jevit jako Simplikiova vlastní vsuvka, motivovaná čistě znalostí obecného iónského vysvětlení umístění Země v univerzu. ${ }^{13}$ Simplikios roli vzduchu nijak blíže nerozvádí a nikde se k ní ve svém komentáři ani nevrací. Snad to lze přičítat zejména faktu, že se zaměřuje pouze na rozbor Aristotelova textu, který se o vzduchu nezmiňuje. Naproti tomu „rovnováhu“ je možné spolu se „souměrností“ nalézt již v bezprostředně předcházející části Simplikiova komentáře k Aristotelově pasáži. A to jak v jeho citaci z Platónova Faidóna, tak ve stanovisku Alexandra z Afrodisiady, které Simplikios uvádí. ${ }^{14} \mathrm{~V}$ každém případě oproti Aristotelovi přidává hned dva další momenty, které měly hrát roli v Anaximandrově výkladu: vzduch a rovnováhu.

Jak jsme uvedli v úvodu, pro nás je zásadní, že Simplikios svůj komentář

\footnotetext{
13 Srov. Kahn 1960, s. 55.

14 Simplikios, In Arist. De caelo 532,1-2; 532,7-12.
} 
začíná upozorněním, že obdobně argumentuje Platón v dialogu Faidón. V rámci své výzvy $\mathrm{k}$ péči o nesmrtelnou duši zde Sókratés předkládá eschatologický mýtus, který líčí její posmrtné osudy (Phd. 107c-115a). Při svém výkladu se přitom dostává i ke kosmologickým otázkám, které se týkají především popisu Země a s osudem duše významně souvisí: ${ }^{15}$

„Jsou pak mnohá podivuhodná místa na zemi a země sama není ani taková[,] ani tak veliká, jak míní ti, kteří mají zvyk o ní vykládat; takového přesvědčení jsem já od kohosi nabyl.“16

Před vlastním popisem podoby Země a míst, která se na ní nalézají, Sókratés nejprve přibližuje právě její nehybné umístění v univerzu, na které Simplikios upozorňuje. Sókratés přitom vychází z předpokladu kulové Země:

„Jsem tedy přesvědčen, pravil Sókratés, že za prvé je-li Země uprostřed nebe

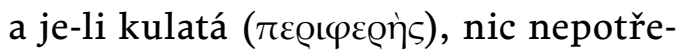
buje - ani vzduchu, aby nespadla, ani žádné jiné takové přírodní síly, nýbrž

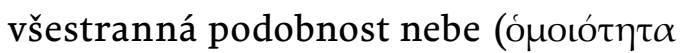

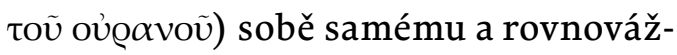
nost (ioo@@otí $\alpha v$ ) samé Země stačí ji držet; nebot' rovnovážná (ioó@@otov) věc položená ve středu něčeho stejnorodého (ónoíov) nemá ani dost málo se

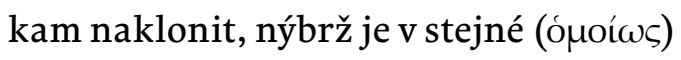
poloze a trvá bez úchylky. “"17

\footnotetext{
15 Srov. Karfík 2007, s. 58.

16 Platón, Phd. 108c. Přel. F. Novotný.

17 Platón, Phd. 108e-109a. Přel. F. Novotný.
}

Tvar Země je charakterizován slo-

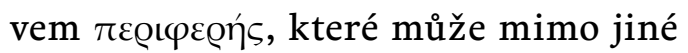
znamenat „okrouhlý“ nebo „kulatý“. Lze se ovšem domnívat, že míněn je právě druhý význam. ${ }^{18}$ Je pozoruhodné, že Platón explicitně vylučuje působení vzduchu a „přírodní síly“ obecně, kterým Simplikios naopak začíná. Z Platónovy pasáže je však evidentní, za jakých předpokladů lze celý argument vést. V prvé řadě se jedná o kulovou Zemi umístěnou ve středu nebe. Zda je analogicky míněn i sférický tvar nebe, však není z textu zcela patrné. V prvé řadě jej může evokovat „střed nebe“ ve smyslu shodné vzdálenosti nebe od svého středu. Právě sférický tvar by měl danou podmínku splnit. Uvidíme však, že střed světa přičítají různí autoři i Anaximandrovi, ačkoli v jeho případě nemáme o tvaru univerza žádné konkrétní zprávy. Ke sférickému tvaru nebe by ovšem měla navíc cílit teze o „všestranné podobnosti nebe sobě samému“, která se skrývá i za zmínkou o stejnorodosti. ${ }^{19}$

Země má být každopádně $v$ něčem umístěna. K nehybnosti Země mají vést jak stejnorodost obklopujícího prostředí, tak její rovnovážné umístění. Je-li uváděna pouze podobnost nebe sobě samému a jeho stejnorodost, zdá se, že jsou zanedbány jakékoli v něm působící privilegované síly a směry. Pokud Sókratés explicitně přisuzuje Zemi tvar koule, lze se domnívat, že sférický tvar univerza je míněn implicitně a skrývá se právě za podobností a stejnorodostí

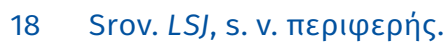

19 Hippolytos, Ref. I,6,3 Marcovich = DK 12 A 11; Theón ze Smyrny, De util. mat. 198,18 $=D K 12 \mathrm{~A} 26$. 
nebe, které jej vyjadřují - koule by měla být jejich celostním a zároveň geometrickým vyjádřením. Argument by tak byl veden na základě shodných - sférických - tvarů jak Země, tak samotného univerza.

Že má Platón opravdu na mysli sférické univerzum, lze odvodit i z jiného jeho textu, dialogu Tímaios, v němž tvůrce dává světu podobu koule (Tim. 33b-c). Následně Platón daný argument užívá v souvislosti s popisem sférického univerza:

„Poněvadž má vesmír podobu koule, všechny body, které jsouce stejně vzdáleny od středu jsou na obvodě, musí být stejně na obvodě, kdežto střed, který jest o tytéž délky vzdálen od bodů obvodu, jest patrně na opačné straně proti nim všem. Když tedy jest vesmír takový, jak by mohl někdo něčemu $z$ připomenutých věcí přikládat název ,nahoře nebo,dole', aby se právem neukázalo, že užívá jména naprosto nepříslušejícího? Nebot'o středním místě v něm nesluší se říkat[,] ani že jest dole, ani že nahoře, nýbrž právě uprostřed; obvod pak není ani uprostřed[,] ani nemá takového rozdílu mezi svými částmi, že by některá byla bližší středu než některá z protilehlých částí. Nuže, jak by bylo správné dávat jakýmkoli způsobem protikladná jména tomu, co je na všech stranách stejné? Nebot' i kdyby bylo uprostřed všehomíra nějaké pevné těleso pravidelné, k žádnému bodu na obvodě by netíhlo, protože jejich poměr je všude stejný.“20

Je to přitom právě shoda mezi sférickým tvarem Země a univerza, na níž celý Aristotelem uváděný argument stojí. Aristotelés ji však opomíjí uvést. Přesto je podoba obou argumentů více než patrná. Simplikios ovšem upozorňuje, že Platón na rozdíl od Aristotela uvádí v dialogu Faidón spolu se souměrností i rovnováhu. Sám oba termíny

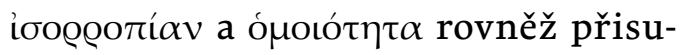
zuje Anaximandrovi, a je tak zřejmé, že je v tomto smyslu poplatný právě Platónovi. Upozorňuje nicméně, že Alexandros z Afrodisiady je pokládal za ekvivalentní. $^{21}$

Jak jsme zmínili, vzhledem k podobnosti obou pasáží u Aristotela a Platóna se lze ptát, zda Aristotelés necílí právě na Platóna. Simplikios si položil tutéž otázku. Na začátku svého komentáře ovšem soudí, že pokud danou koncepci ještě před Platónem zastával Anaximandros, Aristotelés by měl reagovat právě na Mílétana. Aristotelés navíc před inkriminovanou pasáží (De caelo II,13,295b10) ${ }^{22}$ ocitoval část z Tímaia ${ }^{23}$, která podle něho naopak pojednává o pohybu Země kolem osy procházející nebem. Argument o nehybnosti Země by proto Platónovi patřit neměl. ${ }^{24}$

Simplikios ovšem zároveň zachovává názor Alexandra z Afrodisiady, podle něhož Aristotelés formulací „jako ze starých myslitelů Anaximandros"ukazuje, že evidentně existovali myslitelé, kteří nepatřili mezi ony „staré“. Mohlo by se

Simplikios, In Arist. De caelo 535,4-8.

Aristotelés, De caelo 293b30-32.

Platón, Tim. 40b.

Simplikios, In Arist. De caelo 532,2-7. 
tak jednat o Aristotelovy současníky. Navíc není jasné, zda Země měla setrvávat na svém místě zcela nehybně, či zda se pohybovala. ${ }^{25}$

Variuje-li Simplikios s otázkou Anaximandrova autorství Aristotelem zmíněného argumentu, můžeme se ptát, zda se ve skutečnosti nejednalo opravdu spíše o Platóna, u něhož je celý argument dobře doložen. Sókratés ovšem v dialogu Faidón dříve uvádí, že své přesvědčení „od kohosi nabyl“, aniž by ho však jmenoval. ${ }^{26}$ Vzhledem k této Sókratově explicitní zmínce o původním zdroji, z něhož sám čerpal, se můžeme domnívat, že Platón ve skutečnosti zachovává a rozvíjí předchozí pojetí, které se míjelo s tradiční koncepcí podpírání Země.

Aristotelés doslova tvrdí, že Anaximandros danou koncepci zastával jako jeden ze „starých myslitelů“ ( $\tau \tilde{\omega} v$

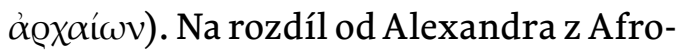
disiady se můžeme domnívat, že touto formulací odhlíží od Platóna jako svého současníka, a naopak cílí do starší doby. Odkaz by tak měl opravdu směřovat až dále před Platóna. Není ale jasné, zda se vztahuje výlučně k Anaximandrovi, nebo je Mílét’an uváděn pouze jako reprezentant uvedené skupiny. Lze poznamenat, že podobným způsobem (byt' $v$ jiném kontextu) jej Aristotelés zmiňuje i ve Fyzice spolu s „většinou badatelů o přírodě“. ${ }^{27}$ Ačkoli bychom mohli celé vyjádření vnímat v tom smyslu, že je míněna pouze Anaximandrova starobylost,

\footnotetext{
25 Simplikios, In Arist. De caelo 532,7-12.

26 Platón, Phd. 108c. Přel. F. Novotný.

27 Aristotelés, Phys. III,4,203b6 = DK 12 A $15=$ DK 12 B 3.
}

nebot' Aristotelés referuje o svých předchůdcích, měli bychom vzít vúvahu možnost, že Aristotelés píše o jiné dřívější koncepci, $\mathrm{k}$ níž se cítil být oprávněn následně přiřadit i Anaximandra.

Anaximandros totiž nemusel být Aristotelovým cílem. Je možné, že je zde zmíněn pouze mimochodem a Aristotelés ve skutečnosti vycházel z Platóna, u něhož se s argumentem seznámil. Platóna však přitom nemusel jmenovat vzhledem k tomu, že si byl vědom, že navazoval na dřívější pojetí. Vždyt Sókratés v dialogu Faidón jasně naznačuje, že zmiňovaná koncepce není nová. ${ }^{28}$

Na textové bázi se opravdu můžeme opřít o konkrétní text, který obsahuje Aristotelem uváděný argument a mírí právě tímto směrem. Jedná se o pasáž z Áetia, která argument přisuzuje hned dvěma myslitelům odlišných dob - Parmenidovi a Démokritovi. ${ }^{29}$

\section{PARMENIDÉS}

Ačkoli bychom očekávali, že Áetiova pasáž bude obsažena v kapitole pojednávající o pohybu Země, zmíněný text je uveden až dále - poněkud překvapivě v kapitole o zemětřesení. Může se proto jednat o jeden z důvodů její možné zmatečnosti. Uvedený text rovněž zachovává pouze jeden z našich zdrojů pro Áetia, Pseudo-Plútarchos:

„Parmenidés a Démokritos [ř́íkají, že Země] zůstává na místě, nebot je od všeho stejně vzdálena. Nalézá se tak v rovnováze (ioo@@oтí $\alpha \varsigma$ ) vzhledem

Srov. Kahn 1960, s. 79-80.

29 Srov. Kahn 1960, s. 79-80. 
k tomu, že nemá důvod, aby se odchylovala tím či oním směrem. Proto se pouze otřásá a nemění své místo.“30

Pokud odhlédneme od vlastního zařazení textu, lze konstatovat, že argument, který pasáž tlumočí, je velmi blízký Aristotelovu znění ze spisu $O$ nebi. Ačkoli opomíjí umístění Země ve středu, není uveden ani tvar Země či okolního prostředí. Oproti „podobnosti“, „stej-

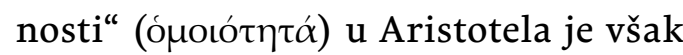
zmíněna „rovnováha“, která se objevuje až u Platóna a Simplikia.

Pokud se nejprve zaměříme na druhého z Áetiem uváděných myslitelů, Démokrita, lze v jeho případě vyslovit další pochybnosti ohledně validity Áetiova textu. Aristotelés mu totiž spolu s Anaximenem a Anaxagorou, tedy ostatními iónskými mysliteli různých dob, připisuje vysvětlení umístění Země v univerzu na základě jejího plochého tvaru a působení vzduchu:

„Anaximenés, Anaxagorás a Démokritos však tvrdí, že příčinou toho, že Země stojí, je její plochost. Nerazí si cestu vzduchem pod sebou, ale přikrývá jej jako poklice, což plochá tělesa zjevně dělají. Ta jsou totiž vůči větru nehybná díky protitlaku. Tvrdí, že takto to činí i Země svou plochostí vůči vzduchu pod sebou. Vzduch nemá dostatečné místo, aby se pohnul, zůstává dole a v klidu, jako voda v klepsydře.“"31

Áetios, Plac. III,15,7 = DK 28 A 44. Přeložil autor.

Aristotelés, De caelo II,13,294b13=DK 13 A 20.
Vzhledem k Aristotelovým referencím se přitom mělo jednat o nejtypičtější vysvětlení nehybného umístění Země. Také Áetios popisuje Démokritovu Zemi ve tvaru disku. ${ }^{32}$ Viděli jsme však, že Platón explicitně uvádí kulový tvar Země jako jednu z podmínek její rovnováhy. Sám Áetios v kapitole o pohybu Země navíc přiznává Démokritovi postupné zastavení jejího pohybu nejspíše právě za předpokladu přítomnosti okolního vzduchu. Původní pohyb Země byl zároveň v rozporu s Aristotelem zmiňovaným argumentem: ${ }^{33}$

„Démokritos [ř́íká, že] Země zpočátku bloudila pro svou malost a lehkost, ale že časem ztuhla, stala se těžkou, a tím se zastavila." 34

Můžeme se tak domnívat, že Démokritovo jméno se v souvislosti s argumentem objevilo omylem či podobně jako v případě Anaximandra - pouze v souvislosti s některým obdobným prvkem jeho kosmologie. Dále se proto zaměřme na prvního z obou myslitelů Parmenida. Zdá se totiž, že u něho můžeme být na dobré stopě.

Parmenidova kosmologie je ovšem naprosto temná a její podoba patrně zůstane silně hypotetická. V této studii si neklademe za cíl ji rekonstruovat, a to ani částečně. Chceme pouze přihlédnout $\mathrm{k}$ některým významným momentům, které by mohly vypovídat

32 Áetios, Plac. III,10,5 = DK 68 A 94.

33 Srov. Kahn 1960, s. 79, pozn. 4.

34 Áetios, Plac. III,13,4 = DK 68 A 95. Přel. K. Svoboda. 
o Parmenidově roli v námi pojednávaném tématu. Nahlédnout, zda Parmenidovo myšlení obsahuje předpoklady, z nichž by mohl Aristotelem uváděný argument vycházet.

Pokud se nejprve zaměříme na to, jaký tvar Země Parmenidés předpokládal, lze v první řadě konstatovat, že Diogenés Laertios mu přisuzuje Zemi ve tvaru koule:

„Parmenidés první prohlásil Zemi za kulovitou a za ležící uprostřed.“"35

Může se ovšem jednat o podobný anachronismus jako v př́ípadě Anaximandra, kterému také připisuje kulovou Zemi. ${ }^{36}$ Když však ještě předtím pojednává o Pýthagorovi, který měl

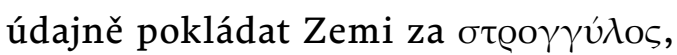
Diogenés připojuje, že tak podle Theofrasta měl jako první učinit Parmenidés. ${ }^{37}$ Význam termínu $\sigma \tau \varrho o \gamma \gamma u ́ \lambda o \varsigma$ však kolísá mezi „okrouhlý“ a „kulový“. V prvním případě by se tak mohlo jednat pouze o Zemi ve tvaru plochého okrouhlého disku. Vzhledem k tomu, že tento tvar Země byl ale obecně zastáván i dříve, lze se domnívat, že míněn by měl být druhý význam, akcentující kulovou Zemi. ${ }^{38}$

Další indicií ve prospěch domněnky, že Parmenidés postuloval kulovou Zemi, by mohl být Anaxagorás, u něhož je dostatečně průkazné, že Zemi pokládal

\footnotetext{
35 DL IX,21 Marcovich $=$ DK 28 A 1.

$36 D L$ II,1 Marcovich $=D K 12 \mathrm{~A} 1$.

37 DL VIII,48 Marcovich = DK 28 A 44.

38 Srov. Graham 2010, s. 241; Kahn 1960, s. 115 .
}

naopak za plochou. ${ }^{39} \mathrm{D}$. Panchenko totiž upozornil na text Martiana Capelly, ${ }^{40}$ v němž se praví, že Anaxagorás měl přinést argumenty ve prospěch koncepce ploché Země zakládající se na zkušenosti s východem a západem Slunce a Měsíce, nebot' linie na obzoru vymezující část nebeského tělesa, zakrytou tělesem Země, je rovná, a nikoli zakřivená, jak by tomu mělo být $\mathrm{v}$ př́ípadě kulové Země. Aristotelés navíc daný argument představuje ve spisu $O$ nebi.${ }^{41}$ Přestože zmiňuje pouze Slunce a neuvádí žádná jména, podporuje tím domnělou Anaxagorovu polemiku s koncepcí kulové Země. D. Panchenko proto vyslovil předpoklad, že pokud měl Anaxagorás argumentovat ve prospěch koncepce ploché Země, musel tímto způsobem polemizovat s koncepcí kulové Země některého ze svých předchůdců. Tím mohl být právě Parmenidés. ${ }^{42}$

Spolu s tvarem samotné Země hraje zásadní roli v Aristotelem uváděném argumentu okolní prostředí - univerzum. O uspořádání, či dokonce tvaru Parmenidova univerza však nemáme žádné zprávy. Autoři se pouze nejasně zmiňují o kruhových věncích či prsten-

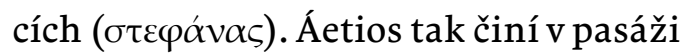
o uspořádání světa:

„O uspořádání světa: Parmenidés tvrdí, že věnce [nebeských sfér] jsou koncentrické, že jeden je z řídkého a jiný

\footnotetext{
39 Hippolytos, Ref. 1,8,3 = DK 59 A 42.

40 Martianus Capella 6,590, $592=$ Gr Axg 40.

41 Aristotelés, De caelo 293b33-294a4.

42 Srov. Graham 2010, s. 241; 2013, s. 96; Panchenko 1997, s. 175-178.
} 
z hustého, že však jsou mezi nimi další, smíšené společně ze světla a tmy. To, co je všechny obklopuje jako hradby, je přispěním Diké tuhé, pod tím je ohnivý věnec. A ten nejvíc uprostřed ze všech kolem je zase ohnivý. Ze smíšených věnců je ten, který je nejvíc uprostřed, pro všechno [principem] a [příčinou] pohybu a vznikání, nazývá jej též jakousi bohyní kormidelnicí a držitelkou klíčů, Spravedlností a Nutností.“43

\section{Podobně dosvědčuje i Cicero:}

„Parmenidés vymyslil věc podobnou věnci, nazývá ji stefané, věnec, totiž souvislý ohnivý kruh obkružující oblohu, který nazývá bohem. (...) Vymyslil též mnoho jiných podobných nehorázností, když povýšil na bohy boj, svár, touhu a jiné věci tohoto druhu, jež hynou nemocí, spánkem, zapomenutím nebo stářím." ${ }^{44}$

Edice Diels-Kranz pak označila za zlomek B 12 vybrané pasáže ze Simplikiova komentáře Aristotelovy Fyziky:

„Užší [věnce] se totiž plnily nesmíšeným ohněm,

\section{(...)}

další pak nocí, vniká však do nich plamenný podíl.

Uprostřed těch [věnců] je bohyně, která řídí všechno, působí totiž všechny hrůzy porodu i páření,

Áetios, Plac. II,7,1 Mansfeld-Runia = DK 28 A 37.

44 Cicero, De nat. deor. I,11,28 = DK 28 A 37. posílá samci samici, aby se pářili, a naopak zase samce samici. ${ }^{“ 45}$

Pokud měla kosmologie představovat závěr Parmenidovy básně, můžeme přihlédnout $\mathrm{k}$ metafyzické části, která jí předcházela. V ní bychom se mohli porozhlédnout, zda nenalezneme některé prvky, které nám pomohou při interpretaci možného vztahu Parmenidova myšlení k Aristotelem uváděnému argumentu o nehybnosti Země. Lze se totiž domnívat, že kosmologie ve skutečnosti představovala klíčovou část Parmenidovy básně. Mohla znamenat přímo vyústění jeho sdělení o pravé povaze tohoto světa. Vždyt' sám Parmenidés, ${ }^{46}$ ačkoli jím líčené uspořádání světa označil pouze za podobné pravdě, je zároveň považoval za nadřazené všem předchozím výkladům. ${ }^{47}$

Shrneme-li základní prvky, na nichž se zakládá argument o nehybnosti Země, vidíme, že se v prvé řadě jedná o rovnováhu, souměrnost a stejnorodost. A jak jsme uvedli, pokud Platón zmiňuje kulovou Zemi uprostřed stejnorodého prostředí, může se konkrétně jednat o kulovou Zemi umístěnou vprostřed sférického univerza. Tedy přesně tak, jak koncipuje svou vizi světa Aristotelés. Jak jsme zmínili, lze se domnívat, že právě z důvodu této analogičnosti věnuje celému argumentu tolik kritické pozornosti.

45 Simplikios, In Arist. Phys. 39,12; 31,10; 34,14 = DK 28 B 12

46 Simplikios, In Arist. Phys. 30,14; 39,1 = DK 28 B 8,51-52; 60-61.

47 Srov. Furley 1987, s. 54-57; Graham 2013, s. 90-91, 96. 
Přihlédneme-li tedy $\mathrm{k}$ předchozí části Parmenidovy básně, shledáme, že obsahuje podobné prvky. Když Parmenidés předkládá podobu pravého jsoucna, které skutečně jest, přičemž nejprve odhaluje, že nevzniká a nezaniká, představuje jeho další charakteristiku - má být souvislé:

„Ani je [jsoucí] nelze rozdělit, vždyt' je celé stejné (ómoĩov),

není ho zde trochu více, což by mohlo spojení bránit,

ani zas trochu méně; vše je přece naplněné jsoucím.

Tím je vše souvislé, nebot' se jsoucím jsoucí se stýká. “" ${ }^{48}$

Jsoucno je zároveň celé totéž a neproměnné:

„Je také nepohnutelné, v sevření mocných pout,

bez počátku a bez ustání, vždyt’ vznik i zánik

daleko zahnány byly, odvrhla je totiž jistota pravdy.

Totéž a v tomtéž trvá, o sobě samo spočívá

a takto stálé zase trvá. Mocná Nutnost je totiž drží

v poutech meze, která je dokola svírá, ježto ustanovení (řád) nemůže být bez konce;

je totiž bez potřeb, by všechno potřebno bylo." 49

48 Simplikios, In Arist. Phys. 144,29 = DK 28 B 8,22-25.

49 Simplikios, In Arist. Phys. 145,27 = DK 28 B 8,26-31.
Závěrečná pasáž shrnuje předchozí argumenty, přičemž akcentuje ohraničenost skutečného jsoucna:

„Nejzazší hranici majíc, je jsoucí ze všech stran zcela

ukončeno a obdobné útvaru vykroužené koule, od středu všude je stejné a ani o málo větší, ani o málo menší nemůže být zde nežli onde.

Není přec nejsoucího, jež by mu bránilo dospět

k stejnosti (ómóv), ani není možno, by jsoucího zde bylo více,

jinde zase méně, než jest, neb celé je neporušeno.

Je totiž sobě odevšad rovné a stejně (ó $\mu \tilde{\omega} \varsigma)$ k mezím spěje. “50

Vidíme, že v metafyzické části Parmenidovy básně potkáváme hned několik momentů, které hrají klíčovou roli v argumentu o nehybnosti Země. Je to zejména právě vnitřní souvislost jsoucna, kterou můžeme vnímat v úzké návaznosti na „všestrannou podobnost nebe sobě samému“, tedy stejnorodost, již zmiňuje Platón. Parmenidés se u Simplikia navíc o pravém jsoucnu vyjadřuje jako o vykroužené, zaoblené „kouli“. Zůstane ovšem předmětem nekončících diskuzí, zda máme jeho slova o podobnosti jsoucna ke kouli brát doslova, či pouze v přeneseném smyslu. Pokud bychom akcentovali kulový tvar pravého jsoucna $\mathrm{v}$ doslovném smyslu, mohl se B 8,42-49. 
stát obecně uplatňovaným vzorem a sehrát významnou roli v celé Parmenidově kosmologii. Parmenidés u Simplikia následně na začátku básně nazývá obdobně

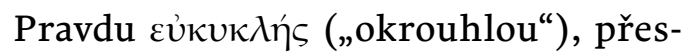
tože ji další autoři naproti tomu vykres-

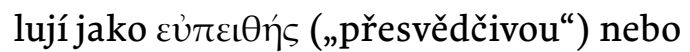

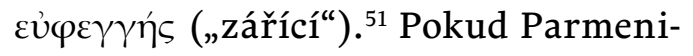
dova slova navíc pochopíme jako vztažená k tomu, co konkrétně opravdu je, mohl by být míněn celek všeho - univerzum. Ve svém důsledku by se tak mohlo jednat o konceptuální akcent na sférické univerzum. Platón a po něm především Aristotelés mohli celý motiv následně konkrétně rozvinout. ${ }^{52}$

Lze pochopitelně namítnout, že nastíněné čtení Parmenidovy koncepce je spekulativní. Přesto se Áetiova zpráva, v níž Parmenidovi připisuje argument o nehybnosti Země, může zakládat na solidních základech již z důvodu výše uvedeného popisu skutečného jsoucna, v němž se objevují takové prvky jako jeho souvislost, která se úzce váže k symetrii. Navíc lze přihlédnout i k výše tlumočené Diogenově zprávě o kulovém tvaru Země, která má ležet uprostřed. ${ }^{53}$ Na základě této zprávy se totiž může zdát, že tvar Země byl přímo spojen s jejím umístěním. ${ }^{54}$

Jiným inspiračním zdrojem, na němž se může zakládat Platónův text a následně z něho vycházet Aristotelův argument, by ovšem mohli být pýthagorejci. U pýthagorejců se objevuje

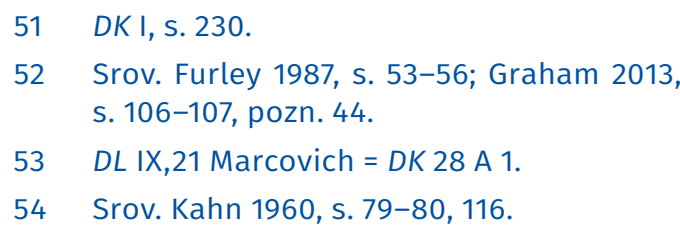

koncepce kulové Země a rovněž symetrie, která se v argumentu uplatňuje, mohla hrát významnou roli v jejich myšlení. Jsou to prokazatelně právě pýthagorejské motivy, které sloužily za podstatný zdroj Platónova výkladu kosmologie. Diogenés Laertios s odvoláním se na Alexandra navíc dokládá, že pýthagorejci se měli domnívat, že nejen Země, ale i celý svět má tvar koule:

„[Svět] má podobu koule obklopující Zemi uprostřed. Ta má rovněž kulový tvar a je na povrchu obydlená. “"55

Není proto vůbec vyloučené, že základní prvky, na nichž je argument o nehybnosti Země postaven, by opravdu mohly vycházet $\mathrm{z}$ pýthagorejského okruhu. Naše konkrétní znalosti o pýthagorejské kosmologii však pocházejí téměř výhradně ze zpráv referujících o Filoláovi z Krotónu. Jakkoli je jeho vliv na Platóna nesporný, Filoláos představuje myslitele, který působil až po Parmenidovi na sklonku 5. století př. Kr. Nacházíme-li tak ještě dříve u Parmenida významné stopy podmínek přítomných $\mathrm{v}$ argumentu, lze soudit, že by měly původně pocházet právě od něho, ačkoli sám mohl na pýthagorejce reagovat. Můžeme navíc poznamenat, že pokud Filoláos ${ }^{56}$ tvrdil, že se uprostřed kolem středu světa nenalézá Země, nýbrž oheň, kolem kterého Země obíhá, formulovaný argument by se k němu vztahovat neměl. ${ }^{57}$

\footnotetext{
55 DL VIII,25 Marcovich $=$ DK 58 B 1a.

56 Áetios, Plac. II,7,7 = DK 44 A 16; Aristotelés, De caelo II,13,293a18 = DK 58 B 37.

57 Srov. Graham 2013, s. 90.
} 
Přestože nemůžeme mít jistotu, na základě uvedených indicií se lze domnívat, že celé pojetí směřuje principiálně k Parmenidovi, který by mohl být adekvátním reprezentantem oné skupiny „starých myslitelů“. Obecně bychom mohli předpokládat, že Platón a následně Aristotelés by měli reagovat právě na Parmenida, a nikoli na Anaximandra. Aristotelés ve svém díle vůbec věnuje Mílétłanovi jen zanedbatelný prostor.

Ačkoli podle D. W. Grahama Parmenidés zřejmě pouze dále rozvíjel koncepci původně navrženou Anaximandrem, můžeme se oprávněně domnívat, že se Graham mýlí. ${ }^{58}$ Uvidíme, že rozdíl mezi výkladem základních rysů univerza, jak byl podán v iónské a naproti tomu v italské větvi filosofie, vypovídá spíše o tom, že argument vychází právě z italského pojetí.

Ve spisu $O$ nebi však Aristotelés zmiňuje Anaximandrovo jméno. Stále tak stojíme před vysvětlením, proč se Anaximandros v dané souvislosti objevuje. Zatímco u Parmenida máme v podstatě k dispozici pouze jediný Áetiův text spolu s nepř́imými indikacemi v popisu jsoucna, pro Anaximandra je textová evidence v tomto směru spíše bohatá. Ve prospěch připsání celé koncepce Anaximandrovi by totiž mohla hovořit předložená svědectví dalších autorů.

Musíme se proto ještě navrátit zpět k Anaximandrovi, abychom znovu poukázali na důvody, které jsme již dříve uvedli, proti přiřazení Aristotelem zmíněného argumentu tomuto mysliteli.

58 Srov. Graham 2013, s. 106; Kahn 1960, s. 115-116.
Spolu se základními charakteristikami Anaximandrova univerza též prozkoumáme obecné rysy archaických iónských kosmologií, abychom na jejich základě mohli rozhodnout, zda argument o nehybnosti Země z důvodu její rovnováhy odpovídá iónskému pojetí.

\section{ANAXIMANDROVA}

\section{KOSMOLOGIE}

Pokud Aristotelés daný argument spojuje jmenovitě pouze s Anaximandrem, není překvapivé, že jeho zprávu po něm tlumočí v různém znění také další autoři, když referují o Mílétanově myšlení. Aristotela v zásadě podporují, ačkoli vlastní argument se u nich spíše vytrácí. V konečném důsledku se tak jedná pouze o dva zdroje, které vysvětlení umístění Země konkrétně traktují. Aristotelovi nejbližší vyznění jádra celé koncepce přitom zaznamenává Hippolytos:

„Země se volně vznáší ( $\mu \varepsilon \tau \varepsilon \dot{c} \omega \varrho o v)$, aniž by byla něčím držena. Setrvává tak, nebot' její vzdálenost je od všeho stejná (ómoí $\alpha v) .{ }^{\text {59 }}$

Hippolytos oproti Aristotelovi ne-

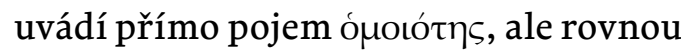
přináší analogický způsob rozvedení celého argumentu, přičemž také užívá termín őjoıos. Hned $\mathrm{v}$ úvodu popisuje volné „vznášení“ Země a explicitně doplňuje, že Země není „ničím držena“. Navíc se vůbec nezmiňuje o první podmínce rovnováhy, tedy o umístění Země ve středu. Ačkoli je lze obecně vyčíst A 11. 
z popisu druhé podmínky, shodné vzdálenosti „od všeho“, je evidentní, že se celkově jedná o autorské převyprávění a zkrácení Aristotelova popisu. V podobném duchu navíc hovoří i Theón ze Smyrny:

„Anaximandros říká, že Země se vznáší

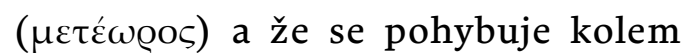
středu světa."60

Theón, stejně tak jako Hippolytos hovoří o „vznášení“ Země. Vynechává ovšem jeho zmínku, že Země není „ničím držena“. Dále akcentuje střed světa, a oproti Hippolytovi tak zachovává první podmínku rovnováhy, kterou zmiňuje Aristotelés. Navíc se nově objevuje pohyb Země, když Theón tvrdí, že se Země kolem středu světa pohybuje. Aristotelés přitom naopak explicitně hovoří o setrvávání v klidu. Pohyb bychom mohli nadto přeneseně chápat i v popisu „vznášení“ Země. Samotné „Vznášení“ nicméně může zastupovat rovnováhu plynoucí z kontextu Aristotelovy pasáže.

Ostatní prameny se $\mathrm{k}$ vysvětlení umístění Země již konkrétně nevyjadřují. Lexikon Súda pouze uvádí umístění Země ve středu. Bez Aristotelova textu bychom se ale mohli domnívat, že jde pouze o obecné kosmologické sdělení, a nedokázali bychom odvodit, že by se mohlo jednat též o první z podmínek rovnováhy Země. Zdůvodnění její stability lexikon ponechává naprosto stranou: DK 12 A 26.
„První objevil rovnodennost, slunovraty a hodiny i to, že Země leží v úplném středu [světa]." ${ }^{\text {"61 }}$

$\mathrm{V}$ podobném duchu se vyjadřuje i Diogenés Laertios. Jeho zpráva je ovšem pozoruhodná nejen mylně uvedeným kulovým tvarem Země, ale rovněž tím, že o umístění Země se vyjadřuje hned dvakrát. Je přitom otázkou, zda dané vyjádření zastupuje obě Aristotelem formulované podmínky rovnováhy. Zatímco druhá poznámka evidentně odkazuje k Aristotelem uváděnému středu, první může reprezentovat umístění Země „stejně vzdálené od krajů“:

„Uprostř̌ed leží Země, která zaujímá střed a má tvar koule."62

Je očividné, že především Hippolytos a Theón $\mathrm{v}$ zásadě vycházejí $\mathrm{z}$ původního peripatetického čtení, které tak či onak podporují nebo z něho přinášejí vybrané či přeformulované části. Ostatní prameny se pak vyslovují pouze k umístění Země ve středu. Nikdo však nezmiňuje konkrétní oporu Země, kterou Aristotelés přisuzuje svým předchůdcům, ani aktivní působení vnějšího prostředí. Může být nicméně pozoruhodné, že Áetios, od něhož pochází jádro kosmologických zpráv k Anaximandrovi a jenž zároveň přináší shodné zdůvodnění nehybnosti Země pro Parmenida a Démokrita, ohledně Mílétana v tomto směru DK 12 A 2.

62 
mlčí. O umístění Země v jeho podání se tak nic nedovídáme.

Abychom si mohli udělat lepší představu o celkovém uspořádání Anaximandrova univerza a o povaze nebeských těles, musíme nejprve přihlédnout ke kosmogonickému procesu, jehož popis přibližuje Pseudo-Plútarchos:

„Říká pak, že to, co rodí teplo a chlad, se při vzniku tohoto světa odloučilo z toho, co trvá, a z něj vyrostla kolem vzduchu, který je okolo Země, jakási planoucí sféra, jako kůra kolem stromu. Když se tato sféra odlámala a uzavřela do jakýchsi kruhů, ustavilo se Slunce, Měsíc a hvězdy."63

Je evidentní, že hlavní roli v procesu postupného ustavování univerza hrály především oheň a vzduch. Dále uvidíme, že vzduch má charakter mlhy, kdy jde de facto o prvotní vlhkost. Po odlámání planoucí sféry se nebeská tělesa následně ustavila v podobě ohnivých kruhů obklopených vzduchem - mlhou:

„Nebeská tělesa jsou jako kruh ohně, odloučila se z ohně, který byl v kosmu, a obklopil je vzduch. Jsou však průduchy jakožto jakési póry na zpo̊sob píštaly, kterými se nebeská tělesa ukazují. Proto také uzavřením těchto průduchů dochází k zatměním."64

Nebeská tělesa, která vidíme na obloze, jsou tak pouhými průduchy na mlžném povrchu celého kruhu daného

63 Pseudo-Plútarchos, Strom. 2 = DK $12 \mathrm{~A} 10$.

64 Hippolytos, Ref. I,6,4 = DK 12 A 11. nebeského tělesa, jimiž se odhaluje vnitřní oheň. Uprostřed těchto ohnivých kruhů obklopených vzduchem mlhou - se nalézá Země. Celé univerzum tak sestává ze Země v jeho středu, kolem níž se soustředně otáčejí kruhy nebeských těles - nejblíže Zemi jsou přitom hvězdy, následované kruhem Měsíce. Slunce se pak nachází v největší vzdálenosti od Země. Zastupuje tak periferii univerza, o níž jinak nemáme u Anaximandra žádné zprávy. ${ }^{65}$

Zatímco nebeská tělesa mají tvar kruhů, Země měla být plochá, ve tvaru válce. Výše jsme ovšem viděli, že Diogenés připisuje Anaximandrově Zemi tvar koule. Mohl však být zmýlen již nejednoznačností Hippolytova slova

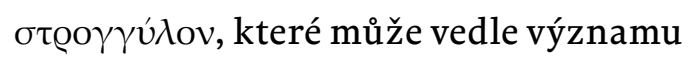
„oblý“, „okrouhlý“ znamenat rovněž „kulatý“. Nejspíše se ovšem bude jednat o důsledek nekritického čtení vycházejícího z pozdní kosmologie. Podobně totiž Diogenés chybuje, když Anaximandrovi připisuje poznatek, že Měsíc je osvětlován Sluncem. Můžeme dokonce zvážit, zda se Diogenův omyl nezakládá na jeho obeznámenosti s argumentem o stabilitě Země, která musela být právě kulová. ${ }^{66}$

Áetios, Plac. II,13,7 Mansfeld-Runia = DK 12 A 18; II,15,6 Mansfeld-Runia = DK 12 A 18; II,16,4 Mansfeld-Runia = DK 12 A 18; II,20,1 Mansfeld-Runia = DK 12 A 21; II,21,1 Mansfeld-Runia = DK 12 A 21; II,24,3 Mansfeld-Runia $=D K 12$ A 21; II,25,1 Mansfeld-Runia $=D K 12$ A 22; II,28,1 Mansfeld-Runia DK 12 A 22; II,29,1 Mansfeld-Runia DK 12 A 22; Achilleus Tatios, Isag. 19,16 = DK 12 A 21; Hippolytos, Ref. Marcovich I,6,4-5 = DK 12 A 11.

$66 D L$ II,1 Marcovich $=$ DK 12 A 1. 
Anaximandros ve skutečnosti nevybočuje $\mathrm{z}$ tradice, podle níž měla být Země plochá. Jedná se přitom o naprosto charakteristický rys iónské kosmologie. Tvar Země měl navíc připodobňovat k nízkému válci, a dokonce jej doprovodit poměry jeho rozměrů:

„Řekl také, že Země je podoby válcové a že její hloubka je třetinou její šířky." ${ }^{\text {"67 }}$

Hippolytos popis doplňuje, když přidává analogii mezi Zemí a sloupem. Oproti celému sloupu, tak jak jej známe z antických chrámů, bychom si ale měli spíše představit pouze jeho část, tzv. buben: ${ }^{68}$

„Její podoba je okrouhlá, oblá, podobá se kamennému sloupu. Na jedné z jeho ploch chodíme, druhá je pak protilehlá."69

Téměř identický text potkáváme rovněž u Áetia, který opakuje paralelu s kamenným sloupem. ${ }^{70}$ Edice Diels-Kranz označila uvedená slova za Anaximandrův přímý zlomek. Nejspíše oprávněně, nebot výklad pomocí analogie ve spojení s konkrétním objektem je pro mílétské myslitele typický. ${ }^{71}$

Samotný povrch Země nebyl nejspíše považován za zcela rovný, nýbrž konkávní, jak bychom mohli vyložit

Pseudo-Plútarchos, Strom. 2 = DK 12 A 10. Srov. Couprie 2011, s. 104-106.

Hippolytos, Ref. I,6,3 Marcovich $=$ DK 12 A 11.

Áetios, Plac. III,10,2 Diels-Kranz = DK 12 A $25=D K 12$ B 5.

Srov. Hahn 2001; 2010.
Hippolytův termín „okrouhlý“ ( $\gamma$ „@óv), ačkoli se v daném případě jedná o opravu původního termínu v́y@òv doloženého v manuskriptu. Konkávní tvar navíc dobře odpovídá řecké představě obývaného světa jako země rozprostřené kolem Středozemního moře. ${ }^{72}$

Výše jsme upozornili, že argument o nehybnosti Země vychází z předpokladu kulového tvaru Země, přímo vztaženého ke stejnorodému prostředí, v němž se Země nalézá - tedy analogicky ke sférickému tvaru univerza. V popisech Anaximandrova univerza a Země přitom potkáváme celou řadu konkrétních tvarů - od planoucí sféry či kruhů nebeských těles po válec Země. Planoucí sféra, která by nejlépe vyhovovala argumentu, však představuje pouze ranou kosmogonickou fázi, nebot' struktura univerza se začne formovat právě až následně po jejím odlámání. Pokud se Slunce nalézá v největší vzdálenosti od Země, a tvoří tak vlastně periferii světa, bývá Anaximandrovo univerzum obvykle badateli pokládáno za otevřené. Je pravděpodobné, že mu Anaximandros nevtiskl žádný konkrétní tvar a pouze popisoval, co konkrétně na nebi pozoruje. Ovšem Leukippovi, který zastával obdobné pořadí nebeských těles - v následnosti Měsíc, hvězdy, Slunce $-{ }^{73}$ přisuzují Áetios s Diogenem naopak membránu, která tvoří hranici světa. ${ }^{74}$ Ačkoli o případném tvaru Anaximandrova univerza se můžeme jen dohadovat, pokládal-li Zemi

72

Srov. Couprie 2011, s. 105-106; Kahn 1960, S. $56,78,81$, pozn. 3 .

73 DL IX,33 Marcovich = DK $67 \mathrm{~A} 1$.

74 Áetios, Plac. II,7,2 = DK 67 A 22; DL IX,32 Marcovich $=D K 67 \mathrm{~A} 1$. 
za plochou ve tvaru válce, nemělo by být možné u něho uplatnit Aristotelem uváděný argument. ${ }^{75}$

Lze nicméně poznamenat, že přestože argument o stabilitě Země zcela neodpovídá poměrům panujícím v Anaximandrově univerzu, badatelé jej obvykle přijímají za platný. U Anaximandra totiž nalézáme prvky, které jej ze hry o formulaci argumentu přece jen nevylučují. Především se jedná o geometrické pozadí, které se v Mílét’anově koncepci zjevně uplatňuje a jež podporuje i lexikon Súda, který o Anaximandrovi tvrdí, že „ukázal základy geometrie“. ${ }^{76}$ Anaximandrovo univerzum zároveň vykazuje zřejmou souměrnost. Můžeme rozpoznat i splnění obou podmínek rovnováhy Země, které zmiňuje Aristotelés: umístění Země ve středu a zároveň shodné vzdálenosti od okrajů. Země se u Anaximandra nalézá ve středu a shodnou vzdáleností od krajů může být míněna vzdálenost Země ke kruhům nebeských těles. Platónem uváděná „stejnorodost“ nebe pak může souviset $\mathrm{s}$ pravidelným tvarem kruhů nebeských těles. ${ }^{77}$

Zárodky celého argumentu lze opravdu spatřovat ve znázornění Anaximandrova univerza jako kruhů ležících v podélné rovině kolem Země. Ačkoli jsme to výše odmítli, na tomto základě bychom mohli spolu s D. W. Grahamem tvrdit, že i když Anaximandros celý argument inicioval, Země u něho ještě není

75 Srov. Furley 1987, s. 27-28; Gregory 2016, s. $133-134,255$, pozn. 57.

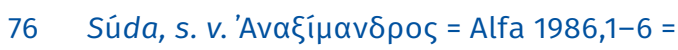
DK 12 A 2.

77 Srov. KRS 2004, s. 173. symetrická. Až v případě Parmenida se v rámci koncepce kulové Země plně uplatňuje symetrie ve všech třech dimenzích. Parmenidés tak mohl rozvinout do plného znění původní Anaximandrovu koncepci. Můžeme pak přímo zvážit, zda Anaximandros nebyl uveden namísto Parmenida v důsledku podobnosti kruhů nebeských těles s Parmenidovými věnci tvořícími univerzum. ${ }^{78}$

R. Hahn v souvislosti s architekturou a stavitelstvím upozornil na to, že argument může reflektovat půdorysný plán budovy. V daném př́ípadě by půdorysný náčrt představoval soustředné kruhy umístěné kolem Země. Ačkoli by se tak Země opravdu nalézala v rovnováze, má Hahnův návrh výraznou slabinu již v tom, že zcela opomíjí pohyb Země, který musel být nejvíce akcentován - pohyb směrem dolů. Lze se totiž domnívat, že primárně se jednalo právě o popis prostého pádu Země, a nikoli pohybu do stran, jak zmiňuje Aristotelés. ${ }^{79}$

Z Aristotelova popisu názorů jeho předchůdců ohledně stability Země je ve spisu $O$ nebi evidentní, že je de facto akcentována pouze otázka pohybu Země směrem dolů. Pokud každá věc směřuje během pádu kolmo k zemi, musela být nastolena otázka, proč sama Země nespadne směrem dolů. Známá Hésiodova pasáž zmiňuje právě tento směr, když uvádí, že kovadlina z bronzu by padala z nebe na zem devět nocí a dní, aby dopadla desátého dne. Stejně tak by následně padala ze země do Tartaru,

Srov. Graham 2013, s. 59, 106; Heath 1913, s. 66.

79 Srov. Hahn 2001, s. $198-200 ; 2010$, s. 56, 64-74. 
aby opět dopadla až desátý den. ${ }^{80}$ Lze se domnívat, že se jedná o důsledky přímo plynoucí z koncepce ploché Země, a tedy lineárně koncipovaného univerza. Argument, připisovaný Aristotelem Anaximandrovi, má však rysy př́íznačné pro koncepci sférického univerza, v němž není žádný upřednostněný směr a pohyby směřují k jeho středu. ${ }^{81}$

Navíc lze připomenout, že zatímco Thalétovi je oproti Anaximandrovi přisuzováno hned pět Eukleidových teorémů, Aristotelés mu zároveň přičítá silně kritizované vysvětlení stability ploché Země nesené vodou. ${ }^{82}$ Jak jsme zmínili, u Anaximandra se ovšem běžně - a v porovnání s Thalétem poněkud překvapivě - akceptuje právě geometrické vysvětlení jako původní. G. S. Kirk dokonce v tomto smyslu konstatuje, že „jeho teorie rovnováhy byla bravurním skokem do říše matematična a a priori“ “83 Anaximandrovo univerzum opravdu vykazuje geometrické prvky a koncepce kruhů nebeských těles parciálně odráží definici přisuzovanou Thalétovi, podle níž se „kruh průměrem dělí na dvě stejné části“"84 a která sama předpokládá definici kruhu. ${ }^{85}$ Někdy se navíc spekuluje, že „sféra“, již Diogenés Laertios ${ }^{86}$ přisuzuje Anaximandrovi, zastupuje model univerza $\mathrm{v}$ podobě soustředných kruhů seskupených kolem Země.

Hésiodos, Theog. 720-725.

Srov. Furley 1987, s. 24-25, 53-54.

Aristotelés, De caelo II,13,294a28 = DK 11 A 14; Met. I,3,983b21=DK $11 \mathrm{~A} 12$.

KRS 2004, s. 173.

Proklos, In Eucl. 157,10 Friedl. = DK 11 A 20.

Srov. Kahn 1960, s. 77-78.

DL II,2 Marcovich = DK $12 \mathrm{~A} 1$.
Pokud však můžeme soudit, iónská geometrie, která se převážně zakládá na kruzích, úhlech a trojúhelnících, má výrazně užitý charakter spojený s konkrétním měřením. Lze tak pochybovat, že v ní již skutečně můžeme spatřovat podobné progresy, jaké představuje konkrétní vizualizace sféry uplatněné v kosmologii, s níž se setkáváme u Filoláa či před ním podle všeho u Parmenida. ${ }^{87}$

Pochází-li navíc Anaximandrova koncepce kruhů nebeských těles pouze z prostého „zhmotnění“ dráhy jejich průduchů, kterou můžeme zejména $\mathrm{v}$ případě Slunce každodenně pozorovat, přičemž nebeská tělesa mají meteorologický charakter, nemusel Aristotelův argument přicházet Mílétanovi ani na mysl. ${ }^{88}$

Ačkoli Anaximandra neztratíme ze zřetele, dále si položíme otázku zejména po obecné povaze iónské kosmologie, nakolik může argumentu sama vůbec odpovídat. Spolu s tím přihlédneme ke styčným předpokladům iónského a italského kosmologického pojetí ve vztahu k pojednávané koncepci stability Země.

\section{IÓNSKÁ VĚTEV FILOSOFIE}

Diogenés Laertios rozlišuje ve svém podání dvě větve filosofie - iónskou a italskou. ${ }^{89}$ Zatímco iónská větev začala podle něho u Anaximandra, který navazoval na Thaléta, ${ }^{90}$ italská větev se počítala od Pýthagory. Diogenés do

87 Srov. Couprie 2003, S. 179; 2011, s. 121; Hahn 2001, s. 6, 56.

88 Srov. Couprie 2011, s. 102.

89 DL I,13 Marcovich.

90 Na jiném místě však Diogenés označí za zakladatele iónské větve Thaléta, kterého jinak radí do mudrcké tradice ( $D L$ I,122 Marcovich). 
ní zároveň řadí i Parmenida. Ačkoli se Diogenova představa vlastně zakládá na geografickém rozdělení myšlení, můžeme opravdu nalézt celou řadu významných odlišností. Zatímco iónská filosofie je typická důrazem na meteorologické jevy a přírodní cykly spolu s přirozenou akcentací náboženské řeči, v italské větvi potkáváme reinkarnaci, uplatnění logiky nebo výrazný akcent na nové užití slova voũs. Lze přitom soudit, že Diogenovu hypotézu o dvou větvích filosofie můžeme dobře využít i pro řešení našeho tématu, nebot' postihuje odlišné rysy kosmologických pojetí. ${ }^{91}$

Na základě dochovaných pramenných textů se lze oprávněně domnívat, že spolu s koncepcí ploché Země je jedním z nejcharakterističtějších znaků archaických iónských kosmologií meteorologický výklad kosmologických jevů. Vzduch představuje prostředí všech dějů, přičemž jeho podoba variuje od temné hutné mlhy, jak poukazuje již Homér, po dýchatelnou, zdánlivě nepostřehnutelnou atmosféru. ${ }^{92}$ Vzduch je onou prvotní vlhkostí, kterou potkáváme u Anaximandra v podobě vzduchu (mlhy) vyplňujícího kosmogonickou planoucí sféru. Tato vlhkost se následně diferencuje na jedné straně do atmosféry, zatímco na straně druhé je jejím pozůstatkem moře. ${ }^{93}$ Oddělením částí vzduchu vzniká vítr a za působení tepla Slunce dochází ke koloběhu vody

\footnotetext{
91 Srov. Kratochvíl 2006, s. 38-39, 41.

92 Srov. LSJ, s. v. áń

93 Áetios, Plac. III,16,1 Diels-Kranz = DK 12 A 27; Alexandros z Afrodisiady, In Arist. Meteor. $67,3-11=D K 12$ A 27; Aristotelés, Meteor. II,1,353b6 = DK $12 \mathrm{~A} 27$.
}

v přírodě. ${ }^{94}$ Vzduch zahrnuje celý svět, a je tak doslova jeho pravým výrazem, jak pro Anaximena dokládá Áetios. ${ }^{95}$ Výrazem jeho celistvosti v proměnách, kterými se každodenně ustavuje.

$\mathrm{V}$ prostředí vyplněném vzduchem dochází k vlastnímu vzniku nebeských těles, který je obvykle spojován s vypařováním vlhkosti z moře a ze země a s jejím následným zapálením. Nebeská tělesa jsou tak obecně vyložena jako meteorologické jevy, přičemž například u Xenofana ${ }^{96}$ se jedná o vznícená oblaka. Se vzduchem je přitom úzce spjata nejen jejich další existence, ale též pohyb, nebot' potřebují svůj oheň stále vyživovat z vlhkosti moře a země. Proto jdou stále za vlhkostí jako za potravou, téměř jako zvířata na pastvě. Aristotelés v tomto duchu píše o obratech nebeských těles:

„[Referát o iónské meteorologii:] [Říkají] totiž, že celá oblast v okolí Země byla dříve vlhká [nebo: byla prvotní vlhkostí], byla však vysušena Sluncem. To, co se vypařilo, prý způsobuje vanutí a obraty Slunce i Měsíce, zatímco to, co zůstalo, je moře. Proto se domnívají, že vysoušením se [moře] zmenšuje a nakonec že jednou úplně vyschne. “97

D. W. Graham tento charakteristický rys iónské kosmologie doslova

94 Áetios, Plac. III,7,1 = DK 12 A 24; Hippolytos,
Ref. I,6,7 = DK 12 A 11; Turba philosopho-
rum 110,15 Ruska = fr. 25 Mansfeld.
95 Áetios, Plac. I,3,4 = DK 13 B 2.
96 Áetios, Plac. II,20,3 = DK 21 A 40; II,25,4 =
DK 21 A 43; III,2,11 = DK 21 A 44; Pseudo-
Plútarchos, Plac. 4 = DK 21 A 32.
97 Aristotelés, Meteor. II,1,353b6 = DK 12 A 27. 
nazývá „meteorologickým modelem“ .98 U Anaximandra je role vzduchu podobně zásadní jako u ostatních iónských myslitelů. Můžeme-li na základě textů soudit, vzduch se v rané fázi kosmogonie nalézal uvnitř planoucí sféry, aby následně obklopil její odlomené ohnivé části, a vytvořil tak mlžný „obal“ nebeských těles. Pokud dosahoval až k nebeským tělesům, která spoluvytvářel, musel zároveň vyplňovat vzniklé univerzum.

Jestliže vzduch vyplňoval celé univerzum, zasahoval i pod Zemi a sloužil jako její opora. D. Furley upozornil, že pokud se Mílétané zajímali o schopnost plochých věcí zůstávat na hladině, Anaximandros mohl v případě ploché Země tvaru válce prostě jen zdůraznit, že taková Země nemá tendenci naklánět se na některou ze stran a zůstává na svém místě na vzduchu. ${ }^{99}$

S tím mohou souviset i zmínky Hippolyta a Theóna o „vznášení“ Země. Užitý termín $\mu \varepsilon \tau \varepsilon ́ \omega \varrho o \varsigma$ totiž spíše upamatovává na dění související s atmosférickými jevy. ${ }^{100}$ Jako by se tak jednalo o rovnováhu Země v okolní atmosféře. Mohli bychom zde spatřovat i návaznost na Platónem zmiňovanou stejnorodost nebe, evokující umístění Země v rovnovážně smíšeném médiu. ${ }^{101}$

Tato rovnováha by však mohla být občas narušována silou větru, který je u Mílétanů pokládán za původce

Srov. Graham 2013, s. 78-84.

Srov. Furley 1987, s. 26-28.

Srov. LSJ, s. v. $\mu \varepsilon т \varepsilon \dot{\varepsilon} \omega \rho \circ$.

Srov. Hobza 2006, s. 388-391; Kratochvíl 2010, s. 226. zemětřesení. ${ }^{102}$ Tím by mohl být míněn pohyb Země, který uvádí Theón. V obdobném duchu tvrdí Seneca, že k zemětřesení mělo podle Thaléta docházet působením rozbouřených vln vody, na níž Země spočívala. ${ }^{103}$ Třebaže Theónova zpráva může být chybná a kıveĩ $\alpha \iota$ může stát na-

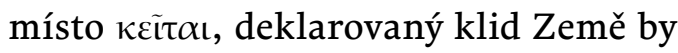
tak nebyl trvalý, pohyby vzduchu by jej čas od času narušovaly. ${ }^{104}$

Přes výraznou úlohu vzduchu však v Anaximandrově koncepci současně nalézáme prvky, které se zdají být výrazně odlišné od běžného iónského způsobu výkladu světa. Je to již povaha nebeských těles, která nevznikají až v důsledku vypařování vlhkosti, nebot' jsou vlastními pozůstatky planoucí sféry. Navíc se jedná o konkrétní tělesa s pevnou strukturou, a nikoli pouze o vznícená oblaka jako v případě Xenofana.

Meteorologické pojetí iónské kosmologie ale především odráží představu, že veškeré dění na nebi se mohlo odehrávat právě pouze nad Zemí. Oba tyto momenty jsou úzce spjaty. Podle všech indicií můžeme soudit, že spojují-li iónské kosmologie vznik a oběh nebeských těles s vlhkostí světa, nemohou tělesa zasahovat pod Zemi. V případě Hérakleita nicméně nemáme o oběhu nebeských těles dostatečné zprávy a u Xenofana rovněž čelíme značným potížím s výkladem celé situace. Pokud je ale pohyb Slunce, které má mít povahu vzníceného oblaku, popisován nejspíše jako

102 Ammianus Marcellinus, Hist. XVII,7,12 = DK 12 A 28.

103 Seneca, Nat. quaest. III,14 = DK 11 A 15.

104 Srov. Kahn 1960, s. 54-55; White 2008, s. 104-105. 
přímočarý, lze se domnívat, že pod Zemi nezasahuje. ${ }^{105} \mathrm{U}$ Anaximena pak autoři opakovaně a jednoznačně dosvědčují, že nebeská tělesa měla obíhat pouze okolo Země, a nikoli pod ní:106

„O oběhu a pohybu nebeských těles: Anaximenés říkal, že hvězdy nekrouží pod Zemí, nýbrž okolo Země.“"107

Jak jsme ovšem zmínili na jiném místě, u Anaximandra je to oproti tomu uváděný sklon kruhů nebeských těles, díky němuž lze předpokládat, že se tělesa pohybují i pod horizontem ploché Země. ${ }^{108}$ Unikátní může být v této souvislosti zpráva o protilehlé straně Země. ${ }^{109}$ Dává dobrý smysl právě v případě popisu Země jako konkrétního tělesa umístěného v prostoru. Země tak nemá žádné kořeny ani se pod ní nenalézá propast Tartaros epické tradice. ${ }^{110}$

Pokud Aristotelés ve spisu $O$ nebi spojuje Anaximandra s argumentem o stabilitě Země a výslovně ho přitom jmenuje, lze se domnívat, že principiálně reaguje na charakteristické rysy jeho kosmologie.

Áetios, Plac. II,20,3 = DK $21 \mathrm{~A} 40 ;$ II,24,4 = DK 21 A 41; II,24,9 = DK 21 A 41a; Hippolytos, Ref. I,14,3 = DK 21 A 33; Pseudo-Plútarchos, Strom. 4 = DK $21 \mathrm{~A} 32$.

106 Áetios, Plac. II,16,5 Mansfeld-Runia = DK13 A 14; Aristotelés, Meteor. II,1,354a28 = DK 13 A 14; DL II,3 Marcovich = DK 13 A 1; Hippolytos, Ref. I,7,6 Marcovich = DK 13 A 7.

107 Áetios, Plac. II,16,5 Mansfeld-Runia = DK 13 A 14.

108 Áetios, Plac. II,25,1 Mansfeld-Runia = DK 12 A 22.

109 Áetios, Plac. III,10,2 Diels-Kranz = DK 12 A 25; Hippolytos, Ref. I,6,3 Marcovich = DK 12 A 11.
Oproti ostatním iónským koncepcím to mohla být právě symetrie uplatňující se $\mathrm{v}$ popisu jeho univerza, sestávajícího z kruhů nebeských těles otáčejících se kolem Země v jejich středu. Klíčovým však byl právě předpoklad oběhu nebeských těles pod Zemí. Ačkoli byla Země obklopena vzduchem, na němž i sama spočívala, nebeská tělesa pod ní procházela, jako by nebyla ničím podpírána. ${ }^{111}$

U Anaxagory, který již ve své době reaguje na myšlení Parmenida, se pak nebeská tělesa stávají konkrétními hmotnými objekty, které se pohybují pod plochou Zemí:

„Slunce svou velikostí přesahuje Peloponés. Měsíc nemá vlastní světlo, nýbrž je má od Slunce. Nebeská tělesa obíhají pod Zemí.“112

Právě zde se ale současně otevírá zásadní problém, který je implicitně obsažen v pozadí všech zpráv. Otevírá se problém univerza jako takového - prostoru, v němž se nalézá Země jako nebeské těleso. Zdá se, že iónské pojetí světa představuje jediné kontinuum, v němž je vznik a pohyb nebeských těles obvykle odvozen od vypařování vlhkosti. Archaická iónská kosmologie ani nezná aristotelské rozdělení světa na sublunární a supralunární oblast nebo Filoláovo odlišení oblastí nebe a kosmu. ${ }^{113}$

111 Srov. Couprie 2011, s. 106-107, 114. D. L. Couprie sice nejprve odmítá Simplikiovu zprávu o aktivní roli vzduchu, nakonec však připouští možnost, že Země byla vzduchem opravdu podpírána.

112 Hippolytos, Ref. I,8,8 Marcovich = DK 59 A 42.

113 Áetios, Plac. II,7,7 = DK 44 A 16. 
V případě iónských kosmologií si na základě dochovaných textů bohužel nemůžeme o pojetí univerza udělat příliš konkrétní představu. Máme k dispozici jen útržky, z nichž můžeme poskládat pouze hrubý nástin celé mozaiky. Můžeme tak sice například dovodit příznačnost meteorologického výkladu, nikoli však již případný obecně uplatňovaný tvar univerza. Není-li ovšem nedostatek zpráv právě v tomto směru signifikantní.

Není ani jednoznačné, zda byla zastávána představa nebeské klenby, která by nesla hvězdy, přikrývala plochou Zemi, a univerzum tak uzavírala, jak se vyvozuje u Homéra. ${ }^{114}$ Můžeme ji však spatřovat za podobnými texty, jako jsou Áetiova vyjádření k Anaximenovi:

„O tvarech hvězd. Anaximenés [říkal, že hvězdy] jsou připevněny $\mathrm{v}$ křištálovém [nebi] jako hřebíky. Někteří je však mají za ohnivé lístky, jako obrázky." ${ }^{115}$

„O nebi, jaká je jeho jsoucnost. Anaximenés tvrdí, že nejzazší okruh je zemitý."

Není-li jasná povaha prostoru nad Zemí, je již naprosto otázkou, zda byl $\mathrm{v}$ archaické iónské kosmologii vůbec řešen problém místa pod Zemí. Pokud ale byly kosmologické děje vysvětlovány meteorologicky a oběh nebeských těles pod Zemi nezasahoval, mělo by se univerzum rozpínat právě pouze v prostoru

Homér, Il. V,504; XVII,425; Od. III,2; XV,329; XVII,565.

Áetios, Plac. II,14,3-4 Mansfeld-Runia = DK 13 A 14.

Áetios, Plac. II,11,1 Mansfeld-Runia $=$ DK 13 A 13. mezi plochou Zemí a nebem. Nebyl by tak předpokládán žádný prostor pod Zemí. Tak bychom mohli rozumět i Hippolytově poznámce o Xenofanovi, podle níž nebyla bezmezná Země obklopena „ani vzduchem, ani nebem“. ${ }^{117}$ Podobně by bylo možné jiný Xenofanův postřeh následně číst v tom smyslu, že dolní hranice země sahá až za naši představivost:118

„U nohou je vidět mez země dosahující sem nahoru, stýká se zde vzduchem, zatímco dolní mez ubíhá k bezmeznu."119

Lze se domnívat, že problém prostoru pod Zemí se jako takový otevřel právě až s příchodem Parmenida. Otevřel se s koncepcí kulové Země umístěné ve sférickém univerzu. Ačkoli se se sférickým tvarem setkáváme opakovaně již u Xenofana v souvislosti s údajným popisem boha, není jasné, zda jej lze uplatnit i na svět. ${ }^{120}$ Navíc se lze domnívat, že popisy tendenčně odrážejí předpokládanou Xenofanovu spřízněnost s eleaty. Pokud ale v iónském archaickém myšlení nebyla nastolena otázka prostoru pod Zemí, problém pádu, a tedy zdůvodnění stability Země nemusel být vůbec nastolen! Aristotelés tak mohl jednotlivým myslitelům daná vysvětlení podsouvat podobně neštastně, jak činil

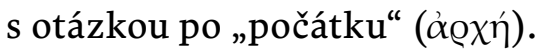

Pouze u Anaximandra máme svědectví o „protilehlé straně Země“, tedy doklad Země jako konkrétního tělesa

\footnotetext{
117 Hippolytos, Ref. I,14,3 = DK 21 A 33.

118 Srov. Lesher 1992, s. 129-131.

119 Achilleus Tatios, Isag. 4, p. 34,11 Maass = DK 21 B 28.

120 Např. Hippolytos, Ref. I,14,2 = DK 21 A 33.
} 
vsazeného do obklopujícího prostředí. $\mathrm{V}$ archaickém iónském myšlení tak de facto nalézáme jediného zástupce pohybu nebeských těles pod Zemí - Anaximandra. Je proto možné, že zprávy, z nichž Aristotelés vycházel, referovaly právě o této skutečnosti. Anaximandros musel být mezi svými iónskými současníky unikátní. Přesto se u něho jednoznačně uplatňuje klíčová role meteorologie a nelze váhat s jeho začleněním do iónské větve filosofie, která se od něho měla začít sama odvíjet.

Je možné se domnívat, že v pozadí všeho je problém prostoru, který s koncepcí univerza přednostně souvisí. Umístění kulové Země ve sférickém univerzu přitom předpokládá schopnost abstraktního uchopení prostoru. Nezná-li však archaická doba abstraktní koncepci prostoru, mohli bychom následně považovat Parmenida za toho, kdo prostor jako první takto tematizoval a zároveň dokázal racionálně vyložit jeho trojdimenzionální pojetí. Ačkoli třetí dimenzi podle všech známek dříve částečně nahlédl již Anaximandros, a mohl být právě proto následně spojen s argumentem o stabilitě Země, nezdá se, že by ji archaická iónská tradice dokázala opravdu adekvátně pojednat. ${ }^{121}$

\section{ZÁVĚREM}

Na základě výše uvedeného lze pochybovat o tom, že Anaximandros zdůvodňoval stabilitu Země v univerzu tak, jak uvádí Aristotelés. Pokud je celý argument založen na shodném tvaru Země a obklopujícího univerza, lze se domnívat, že odpovídá až koncepci kulové Země a sférického univerza, jak ji nacházíme u Platóna. Vzhledem k tomu, že pojetí sférického univerza a Země lze dokladovat u pýthagorejců a v náznacích u Parmenida, můžeme soudit, že jde o pojetí vycházející právě z italské větve filosofie. Již z důvodu nesporného vlivu, který na Platóna oba tyto myšlenkové zdroje měly, se jeví pravděpodobnější, že Platón nechal Sókrata hovořit původně o koncepci italské, a nikoli iónské - navíc Anaximandrově, pocházející ještě z archaické doby. Nemáme-li současně o pýthagorejcích adekvátní texty a opíráme-li se až o pozdní svědectví o Filoláovi, můžeme opatrně vyslovit Parmenidovo jméno. Zvláště pokud mu dané zdůvodnění přisuzuje explicitně Áetios. Právě v Parmenidovi tak nalézáme nejstaršího z možných myslitelů, od nichž by daná koncepce mohla pocházet. 


\section{ZKRATKY}

Seznam zkratek citovaných děl

DK

$G R$

KRS

$L S J$ Widmann. versity Press.
Diels, H., Kranz, W. (1951/1952). Die Fragmente der Vorsokratiker. Griechisch und Deutsch, I-III. Berlin:

Graham, D. W. (2010). The Texts of Early Greek Philosophy. The Complete Fragments and Selected Testimonies of the Major Presocratics, I. Cambridge: Cambridge Uni-

Kirk, G. S., Raven, J. E., Schofield, M. (2004). Předsókratovští filosofové. Kritické dějiny s vybranými texty (přel. F. Karfík, P. Kolev, T. Vítek). Praha: OIKOYMENH.

Liddell, H. G., Scott, R. (1996). A Greek-English Lexicon, With a Revised Supplement: Jones, H. S., McKenzie, R. Oxford: Clarendon Press.

Seznam zkratek antických autorů Áetios

Plac. Placita philosophorum

\section{Achilleus Tatios}

Isag.

Isagoge in Arati Phaenomena

\section{Alexandros z Afrodisiady}

In Arist. Meteor. In Aristotelis Meteorologica commentaria

Ammianus Marcellinus

Hist. Historiae

\section{Aristotelés}

Met.

Meteor.

Phys.

Metaphysica

Meteorologica

Physica

Cicero

De nat. deor. De natura deorum

\section{Diogenés Laertios}

$D L$

Diogenis Laertii Vitae philosophorum

\section{Hésiodos}

Theog.

Theogonia

Hippolytos

Ref.

Refutatio omnium haeresium

\section{Homér}

Il. Ilias

Od. Odyssea

\section{Platón}

Phd.

Phaedo

Tim. Timaeus

Proklos

In Eucl. In primum Euclidis Elementorum librum commentarii

Pseudo-Plútarchos

Strom.

Stromata

\section{Seneca}

Nat.quaest. Naturales quaestiones

Simplikios

In Arist. De caelo In Aristotelis De caelo commentaria

In Arist. Phys. In Aristotelis Physicorum libros commentaria

Theón ze Smyrny

De util. mat. De utilitate mathematicae 


\section{BIBLIOGRAFIE}

\section{Prameny}

Diels, H., Kranz, W. (1951/1952). Die Fragmente der Vorsokratiker. Griechisch und Deutsch, I-III. Berlin: Weidmann.

Graham, D. W. (2010). The Texts of Early Greek Philosophy. The Complete Fragments and Selected Testimonies of the Major Presocratics, I. Cambridge: Cambridge University Press.

Mansfeld, J. (1985). Die Vorsokratiker. Stuttgart: Reclam.

Mansfeld, J., Runia, D. T. (2009). Aëtiana. The Method and Intellectual Context of a Doxographer, II, The Compendium 1. Leiden: Brill.

Marcovich, M. (1986). Hippolytus, Refutatio omnium haeresium. Berlin: Walter de Gruyter.

Marcovich, M. (2008). Diogenis Laertii Vitae philosophorum, I. Berlin: Walter de Gruyter.

\section{České překlady pramenů}

Není-li uvedeno jinak, překlady antických autorů pořídili na základě starších překladů V. Hladký a kol.

Svoboda, K. (ed. a překl.) (1944). Zlomky předsokratovských myslitelů. Praha: Česká akademie věd a umění.

Platón (1994). Faidón (přel. F. Novotný). Praha: ISE.

Platón (1996). Timaios (přel. F. Novotný). Praha: OIKOYMENH.

\section{Slovníky}

Liddell, H. G., Scott, R. (1996). A Greek-English Lexicon, With a Revised Supplement: Jones, H. S., McKenzie, R. Oxford: Clarendon Press.

\section{Sekundární literatura}

Aristotle (2006). On the Heavens, VI (přel. Guthrie, W. K. C.). Cambridge, MA, London: Harvard University Press.

Bodnár, I. M. (1992). „Anaximander on the Stability of the Earth". Phronesis 3, s. 336-342.

Couprie, D. L. (2003). „The Discovery of Space: Anaximander's Astronomy“. In: D. L. Couprie, R. Hahn, G. Naddaf, Anaximander in Context. New Studies in the Origins of Greek Philosophy. Albany: Albany State University of New York Press, s. 165-254.

Couprie, D. L. (2011). Heaven and Earth in Ancient Greek Cosmology. From Thales to Heraclides Ponticus. New York: Springer New York.

Furley, D. (1987). The Greek Cosmologists. I. The Formation of the Atomic Theory and its Earliest Critics. Cambridge: Cambridge University Press.

Graham, D. W. (2010). The Texts of Early Greek Philosophy. The Complete Fragments and Selected Testimonies of the Major Presocratics, I. Cambridge: Cambridge University Press.

Graham, D. W. (2013). Science Before Socrates. Parmenides, Anaxagoras, and the New Astronomy. Oxford, New York: Oxford University Press. 
Gregory, A. (2016). Anaximander. A Re-assessment. London, New York: Bloomsbury Academic.

Hahn, R. (2001). Anaximander and the Architects. The Contributions of Egyptian and Greek Architectural Technologies to the Origins of Greek Philosophy. Albany: Albany State University of New York Press.

Hahn, R. (2010). Archaeology and the Origins of Philosophy. Albany: Albany State University of New York Press.

Heath, T. (1913). Aristarchus of Samos. The Ancient Copernicus. Oxford: Clarendon Press.

Hobza, P. (2006). „Pojetí Země v Anaximandrově kosmologii“. Filosofický časopis 3, s. 381-392.

Kahn, Ch. H. (1960). Anaximander and the Origins of Greek Cosmology. New York: Columbia University Press.

Karfík, F. (2007). Duše a svět. Devět studí $z$ antickéfilosofie. Praha: OIKOYMENH.
Kirk, G. S., Raven, J. E., Schofield, M. (2004). Předsókratovštífilosofové. Kritické dějiny s vybranými texty (přel. F. Karfík, P. Kolev, T. Vítek). Praha: OIKOYMENH.

Kočandrle, R. (2010). Anaximandros z Mílétu. Červený Kostelec: Pavel Mervart.

Kočandrle, R. (2012). „Rovnováha Anaximandrovy Země“. Kuděj 1, s. 6-20.

Kočandrle, R. (2013). „The Earth Floats Unsupported in Space“. In: R. Pisano, D. Capecchi, A. Lukešová (eds.), Physics, Astronomy and Engineering. Proceedings of the $32^{\text {nd }}$ International Congress of the Italian Society of Historians of Physics and Astronomy. Šiauliai: Scientia, cop., s. 39-51.

Kočandrle, R. (2016). „Setrvávání Země v Anaximandrově univerzu“. Filosofický časopis 2, s. 171-188.

Kratochvíl, Z. (2006). Délský potápěč $k$ Hérakleitově řeči. Praha: Hermann \& synové.

Kratochvíl, Z. (2010). Mezi mořem a nebem. Odkaz iónskéarchaické vnímavosti. Červený Kostelec: Pavel Mervart. 
Lesher, J. H. (1992). Xenophanes of Colophon: Fragments. Toronto: University of Toronto Press.

McKirahan, R. D. (1994). Philosophy Before Socrates. An Introduction with Texts and Commentary. Indianapolis, Ind., Cambridge: Hackett.

Panchenko, D. (1997). „Anaxagoras' Argument Against the Sphericity of the Earth“. Hyperboreus 3, s. 175-178.
Robinson, J. (1971). „Anaximander and the Problem of the Earth's Immobility". In: J. P. Anton, G. L. Kustas (eds.), Essays in Ancient Greek Philosophy. Albany: Albany State University of New York Press, s. 111-118.

White, S. A. (2008). „Milesian Measures: Time, Space, and Matter“. In: P. Curd, D. W. Graham (eds.), Presocratic Philosophy. Oxford: Oxford University Press, s. 89-133. 